\title{
O método da autoetnografia na pesquisa sociológica: atores, perspectivas e desafios'
}

\author{
The method of autoethnography in sociological research: \\ actors, prospects and challenges.
}

\author{
Silvio Matheus Alves Santos ${ }^{\mathrm{a}}$
}

Resumo A proposta deste artigo é apresentar a autoetnografia enquanto gênero da etnografia e método de pesquisa qualitativo, visando a entender como alguns aspectos tornam-se importantes para o desenvolvimento de nossa pesquisa doutoral. Dessa forma, objetiva-se expor e desenvolver os aspectos fundamentais e mais específicos do conceito de autoetnografia, suas bases e potencialidades. Assim, pretende-se argumentar que a autoetnografia pode ser reconhecida como metodologia científica e crítica, capaz de desvendar, em sua maneira autorreflexiva, novos e profícuos caminhos para a pesquisa sociológica.

Palavras-chave Autoetnografia; Reflexividade; Pesquisa Qualitativa; Pesquisa Sociológica.

Abstract The purpose of this article is to present autoethnography as a genre of ethnography and as a qualitative research method, aiming at understanding how some aspects become important for the development of our doctoral research. We expose and develop the fundamental and specific aspects of the concept of autoethnography,

1 A realização deste trabalho é fruto de um levantamento bibliográfico para definição e composição da metodologia da pesquisa de doutorado realizada pelo autor deste artigo. Além disso, o desenvolvimento desta pesquisa conta com o apoio de uma bolsa concedida pelo CNPq. Nesta ocasião, expresso meus agradecimentos aos colegas do grupo de discussão que compõem o Seminário de Orientação, a OSET, aos colegas do grupo de discussão "Raça, Desigualdade e Política” que apontaram caminhos e receberam animados os resultados dessa minha reflexão intermediária, com vistas à focalização do projeto de doutorado e à aproximação preliminar com o método autoetnográfico. Estendo os meus agradecimentos aos pareceristas ad hoc que também indicaram aspectos e direções pertinentes para serem trabalhados neste artigo - nem todas as questões foram esgotadas aqui devido aos limites permitidos para um artigo, mas afirmo que tais sugestões certamente deverão ser desenvolvidas no decorrer da tese de doutorado.

a Doutorando do Programa de Pós-Graduação em Sociologia da Universidade de São Paulo - USP. Mestre em Sociologia pela UFSCar (Universidade Federal de São Carlos). Licenciado em Ciências Sociais pela UNESP - Campus/Araraquara e Bacharel em Ciências Sociais pela Universidade Federal de Sergipe. Atualmente é membro do grupo de pesquisa Estudos comparados sobre trabalho e vida econômica: mercados, atores e representações. Atua nas linhas de pesquisa: Mudança econômica e novas configurações das relações de trabalho / Desigualdades, interseccionalidades e políticas de equidade. 
its bases and potentialities. In doing so, we argue that autoethnography can be recognized as a scientific and critical methodology, capable of unveiling, in its selfreflexive way, new and meaningful paths to sociological research.

Keywords Autoethnography; Reflexivity; Qualitative research; Sociological Research.

\section{INTRODUÇÃo}

“[...] As aspirações dos homens negros devem ser respeitadas: a riqueza e a profundidade amarga da sua experiência, os tesouros desconhecidos da sua vida interior, as estranhas voltas da natureza que eles têm visto podem proporcionar ao mundo novas perspectivas e tornar seu afeto, sua vida e sua ação preciosos para todos os corações humanos. E para eles próprios, nesses dias que exasperam suas almas, a oportunidade de voar no pálido ar azul por sobre a fumaça é, para seus espíritos mais requintados, bênção e guarida para tudo aquilo que eles perdem na terra por serem negros.” (Du BoIs, As almas da gente negra, 1999 [1903]).

O início do trabalho em meu projeto de pesquisa para o doutorado teve uma pedra de toque: o uso da memória do Autor, da sua própria experiência vivida, como fonte para descrever a experiência de um trabalhador negro, que confrontou a discriminação e a desigualdade no ambiente de trabalho em sua carreira na mesma empresa que se pretende tomar para estudo de caso. Voltar ao que se viveu durante quase uma década era uma forma de recuperar, nos episódios transcorridos, a matéria prima para mapear como se organizava o trabalho, como teve lugar a inclusão do Autor na empresa, quais barreiras lhe foram impostas em suas tentativas de mobilidade na firma e como as experiências de descobrir tais barreiras, de se sentir discriminado e de tentar superar bloqueios foram vividas pelo Autor. Elaborar analiticamente sobre a própria experiência passada do pesquisador seria, assim, uma forma de recolher informações sobre a gestão das relações e desigualdades raciais no cotidiano de trabalho da empresa, em outro tempo e lugar, criando, assim, um quadro de contraste com o presente a ser estudado. Nesse sentido, o sujeito da experiência adquiria, agora, o estatuto analítico de objeto de observação.

Todavia, vale atentar para o fato de que, nesse caso, há uma longa distância temporal entre o que foi vivido e o registro do que se viveu, o que diferencia esta estratégia de coleta de dados das que vemos nos experimentos de observação participante, que se tornaram comuns na Sociologia do Trabalho. Nestes, a entrada do observador na situação de trabalho se faz pelo fato de ser esta uma situação 
relevante para o objeto que se pesquisa. Tal característica informa não apenas a maneira como se entra na situação, mas o modo como esta é observada e como os registros são colhidos.

Na autoetnografia que pretendo realizar na pesquisa doutoral, a distância temporal é indicativa de uma forma de distanciamento social. No caso presente, a distância temporal testemunha a diferença entre o estatuto que se tinha quando a experiência foi vivida (no caso, a condição de trabalhador subalterno em busca de meios para sobreviver) e o que se passou a ter quando o registro sobre tal experiência foi produzido (no caso, a condição de doutorando em busca de evidências empíricas para sustentar um argumento analítico).

A partir disso, tomando como foco minha pesquisa doutoral, há o intuito de recuperar experiências biográficas, num texto autobiográfico. Dito isso, o relato biográfico individual é um meio para melhor caracterizar a situação de trabalho da perspectiva dos agentes que dela participam. Almejo documentar as desigualdades que nela se expressam, as suas formas racializadas, o modo como os indivíduos expressam a racialização do outro, e como aquele, interpelado por sua origem racial ou discriminado em virtude desta, percebe e elabora tal discriminação.

Por isso mesmo, eu e a minha orientadora consideramos que o uso da autoetnografia seria uma forma preciosa de colher dados sobre um passado vivido, relevante para caracterizar o objeto de estudo. No entanto, acreditamos que o exercício da autoetnografia - que supõe a vigilância (do doutorando e pesquisador) na recomposição da memória (do doutorando e ex-trabalhador) e o seu treinamento para explorar os complexos labirintos da memória da discriminação e do sofrimento - será um meio igualmente fértil para sensibilizar o Autor para o trabalho de observação etnográfica a ser realizado em São Paulo. Igualmente, será um modo único de me aparelhar para explorar os meandros das entrevistas biográficas que planejo colher com trabalhadores em atividade no segmento do comércio varejista de moda.

Neste artigo, apresento algumas questões que visam a destacar a importância do uso do método da autoetnografia. Com isso, pretendo evidenciar a riqueza dessa técnica e argumentar em favor da nossa decisão de adotá-la como uma das fontes de dados nesta pesquisa sociológica.

Convém reiterar, portanto, que o recurso à autoetnografia será usado em apenas uma parte do estudo, a saber, na recomposição de um cotidiano passado, explorando os pontos obscuros em que as estratégias e políticas de gestão da empresa abrem brechas e dão guarida a formas de discriminação. Todavia, para o alcance dos obje- 
tivos da pesquisa doutoral, ele deverá ser complementado, associando-se a outras técnicas de produção de evidências e de construção das bases factuais.

\section{UM PANORAMA DOS DEBATES ATUAIS SOBRE USO, LIMITES E DESAFIOS DA AUTOETNOGRAFIA}

Odeio as viagens e os exploradores. E aqui estou eu disposto a relatar as minhas expedições. Mas quanto tempo para me decidir! Quinze anos passaram desde a data em que deixei o Brasil pela última vez e, durante todos estes anos, muitas vezes acalentei o projeto de começar este livro; de todas as vezes fui detido por uma espécie de vergonha e de repulsa. Pois será mesmo necessário contar minuciosamente tantos pormenores insípidos, tantos acontecimentos insignificantes? (Lévi-Strauss, 1955, p.11)

As we face the coming crises-crisis in our social order, crisis in academia, and crisis in anthropology itself, it behooves us to examine ourselves as a community, as a profession, as an historic development--as a subculture. What is it within us that made for the reactions in the 1960s? What can we learn from our own past that will enable us to meet the challenges that lie ahead? What are our vulnerabilities and our sources of strength? Let us engage in a brief auto-ethnography. In a sense, all ethnography is self-ethnography.

Walter Goldschmidt, Presidential Address no 75th Anniversary Meeting, American Anthropological Association, Washington, D.C., 17.11.1976 (GoldschmidT, 1977, p.293-294)

A maior parte do que eu faço é autoetnografia.

“O que é isso?” Ela [Sylvia] pergunta, escrevendo a palavra autoetnografia em seu bloco de notas e olhando para mim. "Eu começo com a minha vida pessoal. Eu presto atenção aos meus sentimentos físicos, pensamentos e emoções. Eu uso o que eu chamo de introspecção sociológica sistemática e recordação emocional para tentar entender uma experiência que eu vivi. Então, eu escrevo minha experiência como uma história. Ao explorar uma vida particular, eu espero compreender um modo de vida, como diz Reed-Danahay”. “Quem?” Ela pergunta, com a caneta suspensa no ar. "Reed-Danahay, é uma antropóloga que escreveu um livro sobre autoetnografia." "Como faço para obter uma cópia?” [Carolyn diz] 
Não se preocupe com isso ainda. Há muito tempo para ler sobre autoetnografia. Eu quero que você experimente a autoetnografia em primeiro lugar.

Excerto de uma conversa de Sylvia Smith, uma estudante de doutorado em psicologia, com Carolyn Ellis sobre uma possível orientação. (ElLis; Bochner, 2000; grifos colocados)

"Autoetnografia" vem do grego: auto (self = "em si mesmo"), ethnos (nação = no sentido de "um povo ou grupo de pertencimento") e grapho (escrever = "a forma de construção da escrita”)². Assim, já na mera pesquisa da sua origem, a palavra nos remete a um tipo de fazer específico por sua forma de proceder, ou seja, refere-se à maneira de construir um relato ("escrever"), sobre um grupo de pertença ("um povo"), a partir de "si mesmo" (da ótica daquele que escreve).

Grosso modo, podemos dizer que a autoetnografia é um método que se sustenta e se equilibra em um "modelo triádico" (CHANG, 2008) baseado em três orientações: a primeira seria uma orientação metodológica - cuja base é etnográfica e analítica; a segunda, por uma orientação cultural - cuja base é a interpretação: a) dos fatores vividos (a partir da memória), b) do aspecto relacional entre o pesquisador e os sujeitos (e objetos) da pesquisa e c) dos fenômenos sociais investigados; e por último, a orientação do conteúdo - cuja base é a autobiografia aliada a um caráter reflexivo. Isso evidencia que a reflexividade assume um papel muito importante no modelo de investigação autoetnográfico, haja vista que a reflexividade impõe a constante conscientização, avaliação e reavaliação feita pelo pesquisador da sua própria contribuição/influência/forma da pesquisa intersubjetiva e os resultados consequentes da sua investigação³ .

O assim chamado "equilíbrio triádico da autoetnografia", relevante e muito útil em nossa investigação, fica bem visível na ilustração seguinte:

2 Cf. Doloriert e Sambrook (2012) e Reed-Danahay (1997).

3 Para maior desenvolvimento, ver Salzman (2002, p. 806). 


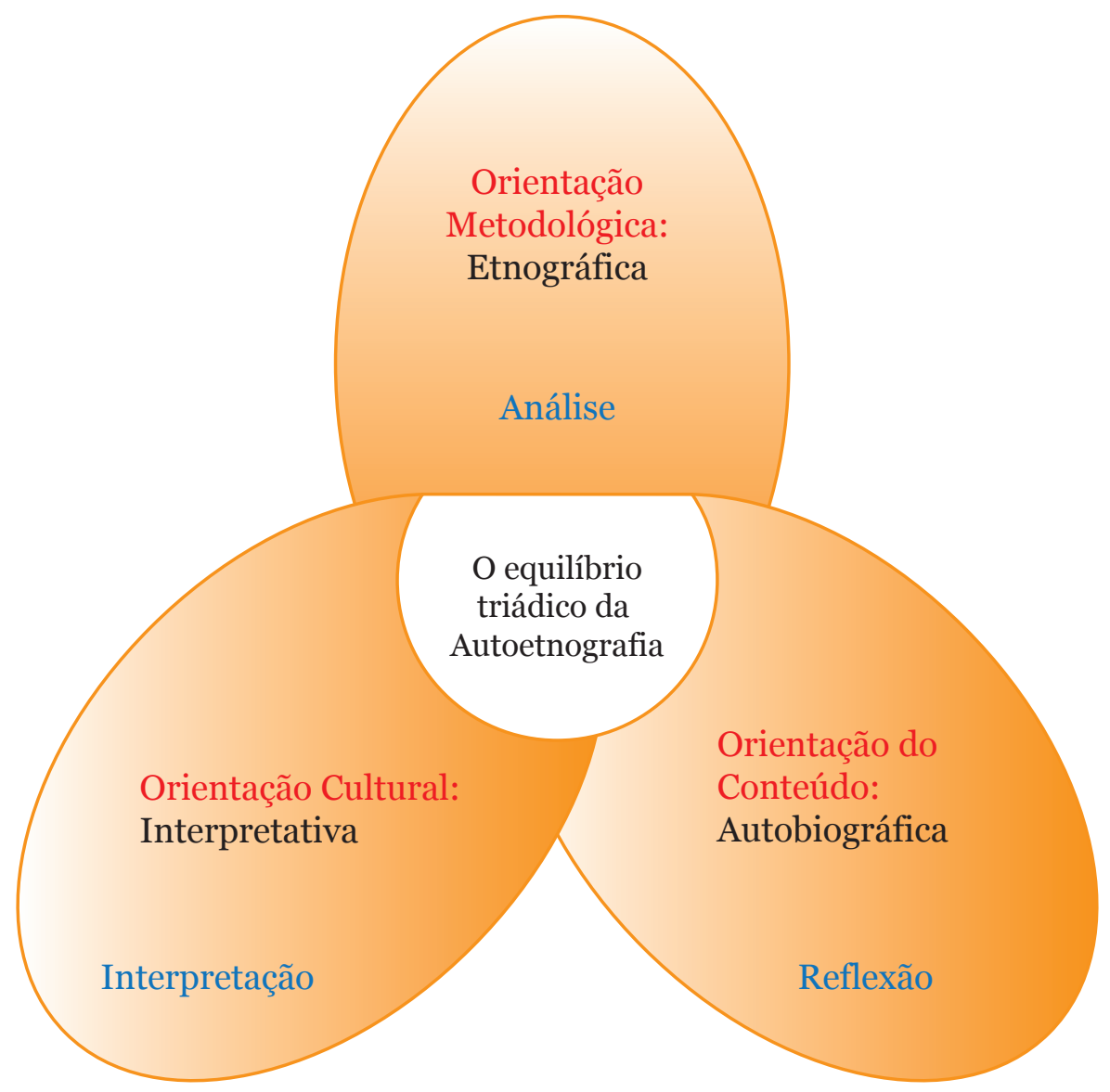

Figura 1. Equilíbrio triádico da autoetnografia ${ }^{4}$

Assim posto, o que caracteriza a especificidade do método autoetnográfico é o reconhecimento e a inclusão da experiência do sujeito pesquisador tanto na definição do que será pesquisado quanto no desenvolvimento da pesquisa (recursos como memória, autobiografia e histórias de vida, por exemplo) e os fatores relacionais que surgem no decorrer da investigação (a experiência de outros sujeitos, barreiras por existir uma maior ou menor proximidade com o tema escolhido, etc.). Dito de outra maneira, o que se destaca nesse método é a importância da narrativa pessoal e das experiências dos sujeitos e autores das pesquisas, o fato de pensar o papel político do autor em relação ao tema, a influência desse autor nas escolhas e direcionamentos investigativos e seus possíveis avanços. Tudo isso tem uma conexão direta com o reconhecimento do caráter político e transformador que tal método assume ao "dar voz para quem fala" e em "favor de quem se fala" (REED-

4 Fonte: Elaboração produzida pelo autor baseado na discussão feita por Chang $(2008$, p. 48) e Snyder (2015). 
-DANAhay, 1997, p.3) - basta pensarmos nos estudos queer, sobre o feminismo, o black feminism e a questão racial.

A autoetnografia é, assim, um método que pode ser usado na investigação e na escrita, já que tem como proposta descrever e analisar sistematicamente a experiência pessoal, a fim de compreender a experiência cultural (ELLIS, 2004). Dessa forma, um pesquisador utiliza princípios de autobiografia e da etnografia para fazer e escrever autoetnografia. Como um método, a autoetnografia torna-se tanto processo como produto da pesquisa (AdAMs; Bochner; Ellis, 2011).

Muitos estudiosos se voltaram para a autoetnografia, nela buscando uma resposta às críticas das "ideias canônicas" sobre o que a pesquisa é e como ela deve ser feita. Em particular, eles queriam se concentrar em maneiras de produzir uma investigação significativa, acessível e evocativa, fundamentada na experiência pessoal, uma pesquisa que sensibilizasse os leitores para questões sobre identidade (numa dimensão política), para experiências envoltas pelo "silêncio" (entendido aqui como silêncio acadêmico, referente a algumas questões sociais) e "formas de representação que visam aprofundar a nossa capacidade de empatia com as pessoas que são diferentes de nós5" (AdAMs; Bochner; Ellis, 2011, p. 274).

Os autoetnógrafos reconhecem as inúmeras maneiras por meio das quais a experiência pessoal pode influenciar no processo de investigação. Por exemplo, um pesquisador decide quem, o quê, quando, onde e como a investigação provavelmente ocorrerá. O pesquisador (ou pesquisadora) também pode mudar nomes e lugares para proteção dos seus sujeitos da pesquisa, comprimir anos de pesquisa em um único texto, construir um estudo de uma forma pré-determinada, por exemplo, usando uma introdução, revisão da literatura, seção de métodos, resultados e conclusão (Ellis; AdAMs; Bochner, 2011). Todavia, se alguns pesquisadores ainda assumem que a pesquisa pode ser feita a partir de uma posição neutra, impessoal e objetiva, outros reconhecem que tal suposição não é mais sustentável (DENZIN; LiNCOLN, 2000).

De acordo com Atkinson (2006), têm existido, efetivamente, muitos trabalhos sociológicos e antropológicos que derivam, em grande medida, do próprio compromisso biográfico do autor num dado mundo social. Quando isso acontece, um possível problema se apresenta. Segundo Atkinson, pode haver uma ênfase excessiva na "abordagem" autobiográfica, a tal ponto que o etnógrafo se torna mais decisivo do que a própria etnografia, ou seja, absorvendo (ou fazendo prevalecer) muito mais a sua memória autobiográfica do que os fatores que cabem aos outros

5 Para mais detalhes, indicamos Ellis e Bochner (2000). 
atores sociais. Em contraponto, autores como Coffey (1999) têm demonstrado que o empreendimento etnográfico é sempre, em algum grau, autoetnográfico, onde o "eu" do etnógrafo é sempre imbricado no processo de investigação. Etnógrafos inevitavelmente influenciam e interagem com as configurações que eles documentam, as quais vão se transformando no processo de pesquisa.

Em suma, e por múltiplas que sejam as perspectivas que adentram ao tema, talvez se possa condensá-las no entendimento de que a autoetnografia é um método de pesquisa que: a) usa a experiência pessoal de um pesquisador para descrever e criticar as crenças culturais, práticas e experiências; b) reconhece e valoriza as relações de um pesquisador com os "outros" (sujeitos da pesquisa) e c) visa a uma profunda e cuidadosa autorreflexão, entendida aqui como reflexividade, para citar e interrogar as interseções entre o pessoal e o político, o sujeito e o social, o micro e o macro.

\section{O LUGAR DA AUTOETNOGRAFIA NOS DEBATES DAS CIÊNCIAS SOCIAIS ${ }^{6}$}

Inserida na tradição interacionista da Escola de Chicago, a autoetnografia deriva da etnografia urbana e organizacional. Esse termo foi usado pela primeira vez, no campo das Ciências Sociais, especificamente na Antropologia, por David M. Hayano (1979). Esse autor nos informa, em seu trabalho, que ouviu esse termo pela primeira vez em 1966, em um seminário sobre estruturalismo na London School of Economics proferido por Sir Raymond Firth (HAYANo, 1979, p. 99).

Em 1975, Karl Heider (1975) usou o termo autoetnografia para descrever um estudo em que os membros de determinadas culturas se referiam à sua própria cultura. Em 1977, Walter Goldschmidt (1977) observou que "toda etnografia" é autoetnografia na medida em que revela investimentos pessoais, interpretações e análises. Em 1979, David Hayano (1979) usou o termo autoetnografia para descrever os antropólogos que conduzem e escrevem etnografias deles mesmos e que escolhem um local ou campo (de pesquisa) para interligar ou "amarrar" uma das suas identidades ou associações de grupo. Para Adams, Jones e Ellis (2015), esses diferentes pontos de vista sobre a autoetnografia configuram algumas possíveis distinções insider-outsider da etnografia.

6 Pensando num dos apontamentos do parecerista ad hoc, entendo que seria pertinente desenvolver uma reflexão mais profunda sobre a localização da autoetnografia no campo do debate da teoria sociológica a fim de compreender as particularidades do método autoetnográfico à luz de algumas tradições sociológicas [W. E. B. Du Bois (1898; 1899 e 1999[1903]), Weber (2006), Bourdieu (2005), etc.], localizando suas raízes e os diálogos estabelecidos com tais tradições. Todavia, a realização de tal empreitada não foi possível neste momento e certamente será enfrentada num próximo artigo. 
Durante a década de 1980, pesquisadores de sociologia, antropologia, comunicação e estudos de gênero começaram a escrever e defender a narrativa pessoal, a subjetividade e a reflexividade na pesquisa, embora não tivessem o costume de usar o termo autoetnografia. Rejeitando a ideia de que os etnógrafos devem - ou podem - perpetuar ou se esconder atrás de um "ideal de objetividade”, esses pesquisadores passaram a se identificar como parte de seus estudos, muitas vezes escrevendo histórias sobre o processo de investigação e, por vezes, sobre suas experiências pessoais. No final dessa década, os estudiosos começaram a aplicar o termo autoetnografia ao trabalho que explorava a interação do introspectivo, o engajamento pessoal do "Eu" (do sujeito pesquisador), os sistemas, as práticas e as crenças culturais e as experiências (AdAMs; ElLIs; Jones, 2015, p. 16-17).

Na década de 1990, alguns pesquisadores começaram a colocar mais ênfase em narrativas pessoais e no desenvolvimento do movimento autoetnográfico. Como exemplo, temos Carolyn Ellis, que publicou um livro e mais de duas dezenas de ensaios sobre autoetnografia, co-editou dois livros sobre "o uso da experiência pessoal na investigação" - Investigating Subjectivity (Ellis; FlaherTy, 1992) e Composing Ethnography (Bochner; ElLIS, 1996). Durante esse tempo, Bochner também publicou ensaios sobre a importância de histórias pessoais e sua relação com a teoria. Juntos, Ellis e Bochner (1996) começaram a editar uma série de livros intitulada Ethnographic Alternatives, que publicava obras que ilustravam como e porque a experiência pessoal deve ser utilizada em pesquisa (ADAMs; ElLis; JonEs; 2015, p. 17).

Na primeira década dos anos 2000 ocorreu a publicação da segunda e terceira edições do Handbook of Qualitative Research (Manual de Pesquisa Qualitativa), ambos contendo ensaios e referências sobre "a etnografia pessoal, experiência pessoal, narrativa pessoal, escrita pessoal, autobiografia e reflexividade" (ADAMs; ELLIS; JoNes, 2015, p. 18), bem como capítulos que focalizam especificamente a autoetnografia, escritos por Carolyn Ellis, Arthur P. Bochner e Stacy Holman Jones. Em 2005, Norman Denzin iniciou o International Congress of Qualitative Inquiry (Congresso Internacional de Pesquisa Qualitativa), uma conferência anual que reconhece a importância da reflexividade e da experiência pessoal na investigação (AdAMs; Ellis; JonEs, 2015, p. 18).

Vê-se, assim, que nesses últimos anos, a autoetnografia tornou-se um método importante e legítimo em muitas disciplinas e contextos de pesquisa. De acordo com Adams, Jones e Ellis (2015), a utilização desse método vem sendo observada em revistas profissionais e em conferências acadêmicas. Numerosos livros e edições especiais de periódicos são dedicados à investigação autoetnográfica, e 
pesquisadores de diversas disciplinas como antropologia, arte e design, negócios, comunicação, criminologia, educação, geografia, enfermagem, psicologia, serviço social e sociologia estão fazendo uso da autoetnografia como um valioso método para a pesquisa.

Se é certo que a autoetnografia não pretende fornecer uma resposta a todas as preocupações intelectuais, estéticas, emocionais e éticas sobre a pesquisa, pode-se, entretanto, dizer que, ao enxergá-la como um método, um modo de representação da experiência do indivíduo/autor/pesquisador e de seu modo de vida, compreendemos que o "fazer autoetnografia" ou o "ser um autoetnógrafo" exige dos pesquisadores uma atenção primordial para a investigação do "eu" em primeiro plano (suas memórias e experiências), para as preocupações representacionais durante todas as etapas do processo de pesquisa (interações com os "outros" - sujeitos investigados - e temas de pesquisa) e a representação desses processos em relação aos contextos social e cultural.

Anderson (2006, p. 384) aponta uma característica central da autoetnografia: "[...] o pesquisador é um ator social altamente visível dentro do texto escrito". Os próprios sentimentos e experiências do pesquisador são incorporados à história e considerados como "dados vitais" para a compreensão do mundo social que está sendo observado.

É certo, e isso foi sublinhado por Atikson (2006, p. 401-402), que todo o trabalho etnográfico implica um grau de envolvimento pessoal com o campo e com os dados (que são sempre construídos e não "dados"). A possibilidade de compreender etnograficamente a vida social, segundo ele, depende de um princípio elementar: a homologia entre os atores sociais que estão sendo estudados e o ator social que dá sentido às suas ações. Com isso, Atkinson nos chama a atenção para o princípio da reflexividade, que no seu entendimento é a linha norteadora da pesquisa etnográfica, tanto quanto da autoetnográfica.

O termo reflexividade tem sido usado (e até abusado) de muitas maneiras na literatura metodológica. Não raras vezes tem sido mobilizado de forma superficial, apenas para aludir a um ato reflexivo; todavia, mesmo nesse sentido, sobressai-se, no ato, o traço de ser dotado de conotações de autoconsciência que ressoam no gênero autoetnográfico (ATKINson, 2006, p. 402). O sentido pleno da reflexividade na etnografia, no entanto, refere-se ao fato inelutável de que o etnógrafo está completamente imbricado nos fenômenos que ele documenta e, também, ao fato de que não pode haver uma "observação" desprendida de uma cena social em que exista um "estado de natureza" independente da presença do observador (como nas relações de entrevistas que são coconstruídas com os informantes). 
Assim pensada, a reflexividade se descola da simples compreensão (não menos importante) de que seria somente um ato de reflexão sobre um fenômeno social, suas causas e seus impactos em determinadas grupos sociais; e vai além, principalmente, quando nos damos conta da sua complexidade e entendemos que essa reflexividade "expressa a consciência de sua conexão necessária com a situação de pesquisa e, portanto, seus efeitos sobre o sujeito pesquisador" (ANDERson, 2006, p. 382) e demais envolvidos na pesquisa:

Numa abordagem mais profunda, esse processo envolve uma consciência da influência recíproca entre etnógrafos, suas configurações e informantes. Implica uma introspecção autoconsciente guiada por um desejo de entender melhor tanto o 'Eu' e os 'Outros' através do exame de suas ações e percepções em referência ao e no diálogo com os outros. (ANDERSON, 2006, p. 382).

Ademais, há que se explorar outra dimensão relevante no emprego da autoetnografia. Tal como tem sido usada, essa técnica reconhece a necessidade de se compreender "como e por que" as identidades tornam-se importantes, bem como "inclui e interroga" as experiências ligadas às diferenças socioculturais. Nesse sentido, a autoetnografia se mostra como uma abordagem que reconhece e envolve a subjetividade, a emotividade e a perspectiva do pesquisador sobre a investigação. Além disso, ela ajuda a ampliar o entendimento das principais questões investigadas (questão racial e estudos de gênero, por exemplo), evitando as definições rígidas, e tornando, dessa forma, a pesquisa mais significativa (pensando no fator analítico/ interpretativo e na dimensão insider do pesquisador em relação ao tema e campo de investigação) e útil (a partir do fator transformativo quando observamos o aspecto político e cultural).

Mas este não é um método de trabalho isento de críticas, algumas delas muito incisivas. Para Delamont (2007), por exemplo, o método autoetnográfico anula o nosso dever de pesquisador, que é sair e coletar dados. Para ela, "nós não recebemos salários generosos para ficarmos sentados em nossos escritórios escrevendo de forma obsessiva sobre nós mesmos" (DELAMont, 2007, p. 3-4). Segundo a autora, a sociologia é uma disciplina empírica e devemos estudar o social. Mais ainda, diz a autora: "nós (pesquisadores) não somos interessantes o suficiente para escrevermos sobre nossas experiências em revistas, para ensinar sobre e para esperar a atenção dos outros. Nós não somos interessantes o suficiente para ser um objeto da sociologia" (2007, p. 3-4). Em sua concepção, as questões que são entendidas como importantes não dizem respeito à "angústia pessoal” - e ainda acrescenta 
que a autoetnografia é cercada de angústias dos sociólogos, sendo esses "um grupo privilegiado de sociólogos qualitativos" (2007, p. 3-4).

Algumas críticas de Delamont (2007) sobre o método autoetnográfico são pertinentes se pensarmos no uso da autoetnografia enquanto o único método para se fazer uma pesquisa empírica, e se essa pesquisa tiver como base só a experiência do autor (sujeito pesquisador) ou a sua história de vida. Realmente é difícil aceitar este método se pensarmos nas relações de singularidades entre as experiências dos sujeitos e as trajetórias individuais de cada um dos envolvidos na investigação sociológica e, a partir disso, buscar generalizações com graus universais de "verdade" sobre determinados fenômenos sociais. Conclusões dessa ordem tornam-se praticamente insustentáveis se unicamente baseadas em evidencias de tipo autoetnográfico.

Mas é certo que a autoetnografia nos permite problematizar o papel do sujeito pesquisador no momento da sua inserção e atuação no campo da pesquisa, nas relações sociais. Sendo assim, podemos pensar que, se o que nós pesquisamos na sociologia são as relações sociais, tecidas a partir das instituições e das interações dos indivíduos, mesmo tendo como meta assegurar uma racionalidade e objetividade, distanciando-nos, enquanto pesquisadores, não podemos negar que fazemos parte desses processos de interação e de relação social. A autoetnografia nos ajuda a pensar reflexivamente esses movimentos que circundam as pesquisas sociológicas, as interações de proximidade do pesquisador e pesquisado e as relações (afinidades políticas, culturais, éticas e raciais) deste pesquisador com o tema e objeto/sujeito da pesquisa.

Isso porque o pesquisador da sociologia geralmente tem um grau de afinidade com o tema ou o campo a ser pesquisado. Por isso mesmo, torna-se importante entender quais são as motivações que levam pesquisadores a buscar determinados temas e a focar em questões específicas. Sendo assim, os processos autoetnográficos assumem o papel de princípios norteadores, fundamentais para compreendermos como a análise científica tenta avançar.

\section{O LUGAR DA AUTOETNOGRAFIA ENTRE AS TÉCNICAS DE ANÁLISE QUALITATIVA}

Apresentar o vigor dessa técnica de produção de dados requer também situar o seu lugar no amplo leque das metodologias qualitativas, do qual faz parte. De acordo com Denzin e Lincoln (2000), a pesquisa qualitativa, além de ser uma atividade situada que localiza o observador (ou pesquisador) no mundo, consiste em um conjunto interpretativo de práticas materiais que tornam o contexto social mais visível. Compreendendo que esse conjunto de práticas pode transformar o 
mundo, esses autores entendem que é por meio do uso de cadernos de campo, entrevistas, conversações, fotografias, gravações e da memória do "eu" que essa transformação ganha força e substancialidade.

É fato que o método qualitativo envolve uma interpretação. Isso significa que os pesquisadores qualitativos estudam fatos, sujeitos (e/ou objetos) e situações sociais em seus ambientes naturais, tentando, com isso, dar sentido ou interpretar fenômenos nos termos dos significados que as pessoas lhes conferem (DEnzin; Lincoln, 2000, p. 3). Sendo assim, há uma variedade de formas de produção de material empírico - estudo de caso; experiência pessoal; introspecção; história de vida; entrevista; artefatos; textos e produção culturais; textos observacional, histórico, interacional e visual. Todas elas são capazes de descrever a rotina, os momentos problemáticos e os sentidos na vida dos indivíduos.

Para Denzin e Lincoln (2000), cada pesquisador fala de dentro de uma comunidade interpretativa distinta que configura, na sua forma especial, os componentes multiculturais que estão presentes no campo da pesquisa qualitativa. Em outras palavras, o método qualitativo é guiado por um conjunto de crenças e de sentimentos do pesquisador sobre o mundo e sobre como este pode ser compreendido e estudado. Nesse sentido, tais autores fornecem alguns exemplos de temas, campos de conhecimento e movimentos sociais que não podem mais ser desconsiderados no universo da investigação científica: eles apontam o feminismo, a questão étnica, o marxismo, os estudos culturais, a questão racial e a teoria queer; todos esses exemplos são vistos como modelos privilegiados numa ontologia real-materialista que no mundo concreto faz uma diferença significativa quando nos atentamos para os termos raça, classe e gênero (DENzin; Lincoln, 2000).

Neste amplo leque de materiais empíricos que se utiliza na pesquisa qualitativa, chamam a atenção o estudo de caso, a experiência pessoal, a introspecção, a história de vida, a entrevista, a observação e a memória. De alguma maneira, esses materiais de investigação relacionam e até compõem a autoetnografia. Mais ainda, Denzin e Lincoln (2000) argumentam que por trás desses processos está sempre presente a biografia pessoal do pesquisador, que fala de uma perspectiva particular de classe, gênero, raça, sexo, cultura e comunidade étnica.

O tema da biografia e autobiografia é fundamental para a estrutura da autoetnografia e, principalmente, para a pesquisa sociológica. Shantz procurou desvendar o que já era chamado de sociologia biográfica ou biografia sociológica: "práticas que envolvem biografia, autobiografia, autoetnografia e várias formas de escritas sobre a vida e apresentações criativas do 'Eu'” (2009, p. 113). Discussões como a dele e a de Stanley (1993), além de demonstrarem os contornos que delimitavam o inte- 
resse dos primeiros pesquisadores voltados a desenvolver a sociologia biográfica, deixam entrever que o campo tem sido um objeto de disputa dentro da sociologia. Até porque a sociologia biográfica oferece aos pesquisadores críticos uma nova ferramenta útil para a compreensão das relações sociais complexas em contextos contemporâneos. Por isso mesmo, nos deteremos em aspectos da autobiografia e sua fundamental relação com a autoetnografia.

Ao entrarmos na questão da biografia ou autobiografia, não podemos esquecer a importância das self-narratives (autonarrativas) no campo da pesquisa qualitativa e no método autoetnográfico. De acordo com Chang (2008), os escritos autonarrativos representam vários gêneros, autorias, focos temáticos e estilos de escritas. Em sua concepção, tais escritos assumem a forma de autobiografia, memória, diário, etc. Para a autora, as autonarrativas assumem aspectos de reflexões pessoais sobre vários temas; algumas usam um modelo mais descritivo de narrativa, como é o caso da memória; outras usam fatos autobiográficos em uma narrativa pessoal erudita; e, por fim, nos apresenta o modelo da autoetnografia que tende a ser mais analítico e interpretativo.

Chang (2008) ainda nos alerta para a relevância da autobiografia principalmente quando ela é escrita por autores(as) negros e negras. Nesse sentido, apresento um rápido exemplo de como Boylorn desenvolve seus estudos e investigações com base na autoetnografia. Em um de seus trabalhos, Boylorn justapõe dois estereótipos (na visão da autora, os principais atribuídos às mulheres negras norte-americanas) com uma análise de classe para investigar as "sobreposições das identidades de raça, classe, gênero e sexo" (2014, p. 131). Ela usa a questão do estereótipo para mostrar como as classificações (ou rotulações) da identidade da mulher negra são frequentemente usadas para limitar e "policiar" suas emoções e comportamentos.

Além disso, Boylorn também olha para as implicações interpessoais que essas restrições têm nas vidas social e emocional das mulheres negras; também discute como classe informa a performance comunicativa do "Eu" da mulher negra. Assim, ela nos oferece um fluxo de histórias pessoais e discurso da cultura popular no intuito de construir um sentido dos "estereótipos como história" e "história como estereótipos” (na dimensão de identidade) (2014, p. 131).

Sendo assim, posso entender que a partir de biografias ou autobiografias como as de Angela Davis, Bell Hooks, Patricia Hill Collins, Audre Lorde, dentre outras tão importantes quanto (pensando à luz das referências utilizadas por Boylorn), o movimento Black Feminist passa a ganhar mais solidez e torna-se um desdobramento que possibilita a reconfiguração das discussões sobre: discriminação, 
hierarquizações e desigualdades, violências e opressões - sejam elas de raça, gênero, classe e sexo - na perspectiva e experiência das mulheres negras. Portanto, é nesse fluxo que algumas autoras na atualidade estão desenvolvendo o que Griffin (2012) chamou de Black Feminist Autoethnography (BFA)7.

Vale ainda reter alguns aspectos das potencialidades do método autoetnográfico ${ }^{8}$. Comecemos pela potencialidade da autoetnografia vis-à-vis a técnica de entrevista. Essa última focaliza os significados produzidos de forma interativa e de maneira dinâmica, atentando para a dinâmica emocional (ou para os aspectos mais sensíveis) que têm lugar na situação da própria entrevista. Embora o foco esteja no participante e em sua história, as palavras, pensamentos e sentimentos do pesquisador também são parte do processo interativo nessa situação de coleta; tal é o caso, por exemplo, da sua motivação pessoal para fazer um projeto, do conhecimento dos temas discutidos e das formas pelas quais o próprio entrevistador pode ter sido tocado (ou transformado) pelo processo de entrevista. Mesmo que a experiência do pesquisador não seja o foco principal, em uma situação de entrevista, sua reflexão pessoal e o contexto se tornam camadas que são acrescentadas à história que está sendo contada sobre os participantes (ADAMs; BochneR; ELLIS, 2011, p. 278).

Já as etnografias reflexivas são maneiras de documentar "as transformações" vividas pelos pesquisadores e são vistas como um resultado da realização do trabalho de campo. Nesse sentido, torna-se necessário enquadrar a investigação existente como uma "fonte de perguntas e comparações" em vez de uma "medida de verdade". Tudo isso, muitas vezes, é entendido de forma controversa, especialmente se tais etnografias reflexivas não forem acompanhadas de análise e/ou conexões com uma literatura acadêmica mais tradicional. Portanto, as "narrativas pessoais" propõem-se a compreender um "eu" ou algum aspecto de uma vida que se entrecruza com o contexto cultural e social, que se conecta a outros participantes (ou sujeitos da pesquisa), e convida os leitores a entrar no mundo do autor e a usar o que lá aprenderam para refletir, compreender e lidar com suas próprias vidas (Ellis, 2004, p. 46).

No que tange ao aspecto ético e relacional da pesquisa autoetnográfica, torna-se primordial a compreensão de que investigadores não existem isoladamente. Logo, os autoetnógrafos, muitas vezes, mantêm e valorizam os laços interpessoais com os seus participantes, tornando a ética relacional mais complexa. Os parti-

7 A expressão poderia ser traduzida ao português como "Autoetnografia de Feminista Negra".

8 E nisso seguimos Adams, Jones e Ellis (2015). 
cipantes, na maioria das vezes, começam como amigos ou tornam-se próximos através do processo de pesquisa. Os autoetnógrafos normalmente não os consideram como "sujeitos impessoais", apenas para serem utilizados como "dados" (AdAMs; Bochner; ElLIS, 2011, p. 281). Ao contrário, os autoetnógrafos consideram as "preocupações relacionais" uma dimensão crucial da investigação, que deve ser elemento prioritário em suas mentes durante todo o processo de pesquisa e de escrita. Em muitas ocasiões, essas “preocupações relacionais” obrigam os autoetnógrafos a mostrar seu trabalho para outras pessoas, ligadas direta ou indiretamente à pesquisa, permitindo que essas pessoas lhes forneçam algumas respostas, ou mesmo um reconhecimento de como elas se sentem sobre o que está sendo escrito (a seu respeito), permitindo-lhes opinar sobre como elas foram representadas no texto (AdAMs; Ellis; Bochner, 2011, p. 281).

De modo semelhante aos etnógrafos tradicionais, os autoetnógrafos também podem ter de proteger a privacidade e a segurança dos sujeitos da pesquisa, alterando características de identificação, como circunstância e temas discutidos ou características como raça, gênero, nome e lugar. Enquanto a essência e o significado da história pesquisada são mais importantes do que a recontagem precisa do detalhe, os autoetnógrafos devem ficar cientes de como esses dispositivos de proteção podem influenciar a integridade de sua investigação, bem como a forma como o seu trabalho será interpretado e compreendido (AdAMs; Bochner; ElLis, 2011, p. 281).

Por fim, quanto à confiabilidade, generalização e validade, muitos dos estudiosos da autoetnografia reconhecem a importância da contingência. Ou seja, sabemos que a memória é falível, que é impossível lembrar ou informar sobre eventos numa linguagem que represente exatamente como esses eventos foram vividos e sentidos. Todavia, não podemos deixar de reconhecer a importância da memória enquanto dado de pesquisa. Nas palavras de Chang (2008, p.71), "a memória pessoal é um bloco de construção da autoetnografia porque o passado dá um contexto para o 'eu' no presente e abre a porta para as riquezas (analíticas) do passado"”.

9 Outra referência importante no que concerne à utilização da memória é a proposta de Ecléa Bosi presente em seu livro Memória e sociedade: lembranças de velho. A autora identifica a memória (ou lembranças) como um grande instrumento de análise social e também reconhece nela um passado vivido que possibilita um aporte de reflexões sobre determinadas situações vivenciadas no tempo atual. "Não há evocação sem uma inteligência do presente, um homem não sabe o que ele é se não for capaz de sair das determinações atuais. Aturada reflexão pode preceder e acompanhar a evocação. Uma lembrança é diamante bruto que precisa ser lapidado pelo espírito. Sem o trabalho da reflexão e da localização, seria uma imagem fugidia” (Bosi, 1994, p. 81). 
Portanto, a confiabilidade está estreitamente relacionada às questões de validade. Para os autoetnógrafos, validade significa que um trabalho busca verossimilhança, procura evocar nos leitores a sensação de que a experiência descrita é realista, crível e possível, demonstrando que a história é coerente e que conecta leitores a escritores. Nesse caso, a generalização decorre do fato de um autoetnógrafo específico ser capaz de iluminar (de forma geral) processos (culturais) sociais desconhecidos (Bochner; Ellis, 2000). Desse modo, os leitores fornecem um certo tipo de

validação ao compararem suas vidas às nossas, por pensarem em como nossas vidas são semelhantes e diferentes, às suas razões e por sentirem que as histórias têm lhes informado sobre pessoas ou vidas desconhecidas (ELLIS, 2004, p. 195).

\section{ESCREVENDO DE MODO AUTOETNOGRÁFICO: POR QUE E COMO}

No que se refere ao fazer autoetnográfico enquanto processo, sabe-se que os autoetnógrafos costumam não apenas usar suas ferramentas metodológicas e a literatura para analisar a experiência, mas também devem usar a experiência pessoal para ilustrar facetas da experiência sociocultural e, ao fazê-lo, expor os aspectos singulares e familiares para os insiders e os outsiders.

Pensando na escrita enquanto produto, entende-se que uma autobiografia ${ }^{10}$ também deve ilustrar novas perspectivas sobre a experiência pessoal. Autobiógrafos podem fazer textos estéticos e evocativos usando técnicas de "demonstração", que são projetadas para trazer "os leitores para a cena" - particularmente em pensamentos, emoções e ações (Ellis, 2004, p. 142) - a fim de experimentar uma experiência (Bochner; Ellis, 2006). Já quando os pesquisadores escrevem autoetnografias, procuram produzir descrições densas, estéticas e evocativas da experiência pessoal e interpessoal. Assim, o autoetnógrafo não só tenta fazer da

10 Embora a autobiografia e a autoetnografia possam parecer sinônimos, a literatura no campo é incisiva em sublinhar que se trata de dois processos diferentes e que se complementam. O primeiro, além de ser visto como uma peça literária, traz consigo o fator biográfico do autor e suas reflexões sobre os processos vividos ou experienciados (no campo teórico, na vida pessoal e/ou acadêmica). Nesse sentido, Chang (2008, p. 48) enfatiza que "a riqueza da narrativa autobiográfica e dos insights autobiográficos é avaliada e intencionalmente integrada ao processo de pesquisa, tornando-se, assim, um produto contrário à etnografia convencional”. Explicamos um pouco desse sentido quando falamos sobre as orientações que formam o equilíbrio triádico da autoetnografia. Sendo assim, ao complementar-se com a autoetnografia, que seria a segunda peça analítico-interpretativa/científica, notamos que alguns desses aspectos que constituem a dimensão biográfica ou autobiográfica da vida do sujeito pesquisador (ou autor) se tornam foco de pesquisa. 
experiência pessoal uma experiência envolvente e significativa cultural e socialmente, mas também, através da produção de textos acessíveis, ele ou ela pode alcançar um público mais amplo e diverso, o qual a pesquisa tradicional geralmente "ignora" (ou não atinge).

Entretanto, as nuances e complexidades das identidades, das vidas, dos relacionamentos e das experiências não são facilmente ou ordenadamente traduzidas em uma experiência, em uma pesquisa ou lista de perguntas para entrevista. Nesse sentido, a autoetnografia tem um conjunto comum de prioridades, preocupações e modos de realizar a pesquisa. Essas prioridades da autoetnografia são: a) a experiência pessoal na pesquisa e na escrita vem em primeiro plano; b) apresentar os processos de tomada de sentido; c) usar e demonstrar reflexividade; d) apresentar um conhecimento fruto da informação privilegiada de um fenômeno experiência social (ou cultural); e) descrever e criticar normas culturais, experiências e práticas; ef) procurar respostas nas audiências (com os leitores, pares e sujeitos pesquisados) (AdAMs; ElLIS; JoNES, 2015, p. 25-26).

Ademais, Adams, Ellis e Jones (2015, p. 36) sugerem que, além de entender e abraçar os ideais centrais da autoetnografia e engajar nas abordagens do "fazer autoetnográfico" acima mencionados, os pesquisadores também devem considerar o porquê de eles quererem fazer autoetnografia. De acordo com esses autores, existem quatro razões fundamentais para realizar a autoetnografia, são elas: 1) realizar uma crítica mais contundente, fazer contribuições e/ou estender a pesquisa e teoria existente; 2) abraçar a vulnerabilidade como uma maneira de compreender as emoções e melhorar a vida social; 3) interromper tabus, quebrar silêncios e recuperar vozes perdidas e desconsideradas; e 4) tornar a pesquisa acessível a diversos públicos ${ }^{11}$.

A partir disso, os autoetnógrafos geralmente fazem suas escolhas a fim de chamar a atenção para as vulnerabilidades, as perguntas, as injustiças e os silenciamentos. Eles abrangem a vulnerabilidade com um propósito. ${ }^{12}$ Logo,

a exposição do 'Eu' que também é um espectador tem que nos levar a algum lugar onde não poderiam chegar. Tem que ser essencial para o argumento, não

11 Ver os trabalhos de Boylorn (2014), Griffin (2012) e Romo (2004).

12 "Existe a vulnerabilidade de revelar-se, de não ser capaz de tomar de volta o que você escreveu ou ter qualquer controle sobre como os leitores vão interpretá-lo. É difícil não sentir que sua vida está sendo criticada, bem como o seu trabalho. [...] Também existem muitas recompensas, por exemplo, você vem a compreender a si mesmo de maneira mais profunda. E com a compreensão de si mesmo passamos a compreender os outros. A autoetnografia fornece uma avenida para fazer algo significativo para si e para o mundo [...]" (Bochner; Ellis, 2000, p. 738). 
um floreio decorativo, não uma exposição para o seu próprio bem (ADAMS; ELLIS; JoNES, 2015, p. 40).

Neste caso, a trajetória de dentro para fora da autoetnografia também descreve como começamos um projeto de pesquisa. Muitas vezes, os projetos de investigação começam com acontecimentos que nos transformam (o nosso pensamento, sentimentos, senso de si e do mundo) e também aos outros (nossos amigos e famílias, membros das nossas comunidades sociais, políticas e culturais, e outros que são diferentes de nós) do avesso. Portanto, as autoetnografias começam com os pensamentos, sentimentos, identidades e experiências que "nos arremessam num circuito de tomada de sentido", que nos fazem "perguntar, reconsiderar e reordenar nossa compreensão sobre nós mesmos, os outros e nossos mundos" (AdAMs; Ellis; Jones, 2015, p. 47).

No entanto, alguns aspectos cruciais decorrem e desafiam o exercício desse tipo de abordagem. Como vamos organizar, usar e dar sentido a essa complicada e talvez esmagadora massa de informações decorrentes das expressões e vivências do cotidiano autoetnografado? Por outro lado, como contamos a história de nós mesmos dentro e ao lado de uma história de cultura? Essas questões ou perguntas podem ser úteis para começarmos o trabalho de interpretação e análise através da criação de temas para as ideias, interações e percepções que nós geramos no campo.

No que tange à representação da autoetnografia, a escrita joga um papel decisivo nesse esforço por conhecer/revelar uma experiência diferente. As autoetnografias muitas vezes começam como entradas de diários, narrativas, poesia, blogs ou outras formas de escrita pessoal, em que os autores exploram as suas experiências com o objetivo de compreendê-las.

Do ponto de vista da narrativa formal, os autoetnógrafos muitas vezes escrevem usando a voz na primeira pessoa ou o seu ponto de vista, ou seja, o posicionamento do pesquisador como o narrador da história. O ponto de vista da primeira pessoa é decididamente subjetivo, porque o narrador relata o que ele ou ela observa (ou observou), as experiências, os saberes e o sentimento que fornece aos leitores sobre seus relatos enquanto uma testemunha ocular do fato vivido. Os narradores em primeira pessoa convidam os leitores a se colocarem no interior da ação, nas mentes, nos corações e nos corpos dos narradores (ADAMs; ElLIs; Jones, 2015, p. 78). No entanto, autoetnógrafos também podem usar a voz na segunda pessoa ou o seu ponto de vista; assim fazendo, o leitor é interpelado como "você". Os narradores em segunda pessoa levam os leitores a imaginar que eles mesmos estão vivendo uma cena, evento ou experiência. Por fim, há os autoetnógrafos que 
costumam usar a voz em terceira pessoa para descrever as experiências, pensamentos, sentimentos e ações dos personagens. Os narradores em terceira pessoa frequentemente almejam sugerir uma atmosfera de maior objetividade.

\section{MATHEUS, A FAST FASHIONE A EXPERIÊNCIA DA DISCRIMINAÇÃO}

"Matheus" foi o nome escolhido para identificar o personagem chave que viveu as experiências de trabalho (e de discriminação) enquanto um trabalhador negro na fast fashion ${ }^{13}$ do comércio varejista de moda no final de 1999 (enquanto temporário/terceirizado) e inicio dos anos 2000 (já efetivo - com contrato de duração indeterminada). Tais experiências serão sistematizadas, enquanto evidências empíricas, pelo autor do artigo, a quem caberá extrair as lembranças do vivido, recuperando-as nos labirintos da memória, dando-lhes sistematicidade de modo a poder refletir sobre as mesmas. As reflexões feitas pelo Autor sobre os fatos do cotidiano vivido por "Matheus" serão apresentadas na forma de notas de rodapé ${ }^{14}$. Com isso se pretende separar, e deixar evidente para melhor identificação pelo leitor (i) o que é relato autobiográfico acerca do passado e (ii) o que são observações analíticas sobre este passado, formuladas no presente e já informadas pela teorização que se maneja. Nesse sentido, os rodapés terão um sentido especial. Longe de conterem informações apenas complementares e, por isso, eventualmente descartáveis, aqui eles conterão sempre uma informação analítica chave. Isso porque neles estarão indicadas as pistas interpretativas que se pretende vir a explorar no texto da tese. Assim fazendo, os rodapés também sugerem quais são

13 Choi (2014, p. 3) sustenta que existe uma compreensão mais profunda sobre o termo fast fashion. Este sistema se apresenta como uma tendência industrial que se refere ao conceito de encurtar o tempo de espera (da produção, da distribuição, etc.) e da oferta de novos produtos no mercado, fazendo-o do modo mais rápido possível. Hoje em dia, este recurso é comumente utilizado em vestuário de moda (por marcas como a Zara, Topshop, H\&M, dentre outras) e no consumo de eletrônicos da moda (por exemplo, I-Phone). Pensando num modelo analítico, os principais componentes destes assim-chamados Fast Fashion Systems incluem: a) política de respostas rápidas que são empregadas para reduzir o tempo de resposta do sistema (ou seja, o tempo de espera) para que a volatilidade da oferta e da procura possam ter um melhor equilíbrio; b) sortimento de produtos que mudam frequentemente; c) assegurar que o ciclo de vida do produto seja muito curto; e d) que o projeto do produto se adapte às necessidades das tendências de moda e do mercado. Outra explicação mais simples e mais difundida pelo setor do comércio varejista de moda diz o seguinte: fast-fashion, "(traduzido como moda rápida), é o termo utilizado por marcas que possuem uma política de produção rápida e contínua de suas peças, trocando as coleções semanalmente, ou até diariamente, levando ao consumidor as últimas tendências da moda em tempo recorde e com preços acessíveis." Explicação obtida nos sites: http://www.revide. com.br/editorias/moda/o-conceito-de-fast-fashion/ e http://moda.ig.com.br/modanomundo/ voce-sabe-o-que-e-fast-fashion/n1237795692971.html. Acesso em o4 de março de 2013.

14 Entendendo os limites e dimensões do artigo, optei por trazer alguns apontamentos em notas de rodapés, mas informo que tais análises virão no corpo do texto no desenvolver analítico da tese. Portanto, este não será o modelo utilizado no desenho final da tese doutoral. 
os elementos da narrativa autobiográfica que parecem, ao menos neste momento, especialmente relevantes do ponto de vista etnográfico.

A escolha de "Matheus" como nome para o personagem desse primeiro relato biográfico (uma escolha conjunta, do Autor e orientadora) tinha um duplo endereço. Por um lado, ela recaiu sobre um dos prenomes do Autor, "Matheus", a indicar o sentido autobiográfico do relato, ou seja, que o próprio, "Silvio Matheus", é a fonte de informações. Por outro lado, o prenome escolhido é justamente aquele que não é costumeiramente utilizado pelo Autor nas suas interações. Quisemos, assim fazendo, lançar mão, já desde o início, de um recurso que nos permitisse (à orientadora e ao Autor) incitar o distanciamento analítico de "Silvio", o Autor, quando se reportasse à tarefa de reconstituição sistemática e analiticamente informada da memória de "Matheus", o trabalhador da fast fashion" ${ }^{15}$. Assim, nesta parte do artigo, será "Matheus", e não "Silvio", o sujeito de certa experiência pretérita no trabalho, vivida no mesmo setor e na mesma empresa que "Silvio" estudará no presente. Se, assim fazendo, o texto ganha atrativo do ponto de vista estilístico, cremos, também, que a estratégia nos assegurará que o Autor estará sendo permanentemente instado, do ponto de vista analítico, a lidar com a tensa relação entre vivência e relato, entre "Matheus" e "Silvio", resguardando a almejada reflexividade que deve mover a análise nesse momento.

A seguir, apresenta-se um pequeno recorte de uma das formulações ainda inicial dos registros produzidos sobre momentos-chave da vivência do Autor na empresa, recuperados de modo autoetnográfico, de maneira a exemplificar, com evidências analiticamente relevantes, o quanto poderá vir a luz à medida que se avance e complete esse trabalho de sistematizar tal memória.

\section{A OPORTUNIDADE NA FAST FASHION E A SELEÇÃO PARA O EMPREGO}

[...] Decidi procurar emprego, e esta ideia não saía mais da minha cabeça. Na escola, estudando no ensino médio, ${ }^{16}$ dias depois de ter visitado meu pai no trabalho, perdi uma "chance" de forma tão besta que nem eu acreditei. O McDonald's, uma empresa que estava abrindo filiais em Aracaju/SE, estava recrutando estudantes e

15 Esta fast fashion tornou-se uma das maiores cadeias mundiais de varejo de moda para mulheres, homens e crianças. Com uma grande variedade de marcas, a empresa opera em 21 países da Europa, com mais de 1.500 lojas na Europa e 35 lojas na Ásia. Possui lojas na América Latina (Brasil e México) e também na China. Contava, até o momento da pesquisa de Mestrado do Autor, em 2013, com um total de 1.829 unidades espalhadas pelo mundo (SANTos, 2013).

16 Vale ressaltar que Matheus nesse momento era estudante do $2^{\circ}$ ano do Ensino Médio e tinha 18 anos de idade. Ele estudou em uma escola pública localizada no centro da cidade de Aracaju. Era composta por estudantes de classe baixa e média. Ele pegava dois ônibus para ir e voltar. A escola era conhecida como uma das melhores escolas públicas da cidade. 
dando-lhes a primeira oportunidade de ter um emprego. Bastava preencher, no dia, uma ficha e ter uma foto 3x4 para que pudesse fazer parte da seleção e concorrer a uma vaga para integrar o quadro de funcionários da empresa. Acreditem! Vasculhei minha carteira e minha mochila, de cima a baixo e nada; eu não tinha uma foto $3 \times 4$ e infelizmente não pude fazer parte da seleção. Passado o período de frustração, segui em frente na minha busca.

Num passeio com dois amigos da escola ao Shopping Jardins $\mathbf{s}^{17}$, eu vi um cartaz da fast fashion que me chamou muito a atenção. O cartaz tinha um título e se chamava "Carol e Alex"; eles formavam um casal de jovens brancos, entre seus 18 a 25 anos aparentemente, bem "descolados" e vestindo roupas casuais (simples camisas básicas e calças jeans); com dizeres que passavam a seguinte ideia: "Se você procura seu primeiro emprego e não tem experiência ${ }^{18}$, isso não é problema para a 'empresa X', preencha o 'Carol e Alex' e deixe na nossa loja." Resumindo, essa empresa dava oportunidade para pessoas que nunca trabalharam e que queriam a chance de entrar para o mercado de trabalho. Eu não pensei duas vezes! Entrei na loja e perguntei onde retirava o "Carol e Alex" para preencher.

Nesse momento, uma das falas dos meus dois amigos (negros e com tom de pele um pouco mais escuro que o meu) me fez parar repentinamente e pensar se teria condições de trabalhar ali. Nelson ${ }^{19}$, um dos amigos, falou: "Esquece, Negãoº!

17 O Shopping Jardins foi inaugurado em 20 de novembro de 1997, ele está localizado em um bairro que foi impulsionado pela inauguração desse Shopping e hoje é visto e conhecido como o "nobre e moderno bairro Jardins". Predominantemente visto, na época, como um bairro de classe média/ alta, segue sendo assim classificado. Essa ida de Matheus e seus amigos ao shopping ocorreu no ano de 1999, sem a pretensão de achar um emprego. Era comum os jovens saírem da escola e irem passear em shopping. Apesar de ter a esperança de conseguir um emprego, Matheus não tinha a mínima ideia se o período era ou não de expansão do mercado de trabalho.

18 O fato de a "experiência não ser um problema" para essa empresa nos possibilita pensar que para outras empresas, ou setores, a falta desse requisito era um problema. Pensando no anúncio do Mcdonald's, relatado por Matheus, que se volta para os jovens que desejam uma oportunidade de emprego e nunca trabalharam, entendo que tanto a ação da cadeia de fast food como o anúncio da fast fashion à época não tinham nenhuma motivação altruísta como pano de fundo. Na realidade, tais empresas acabam contratando jovens que nunca trabalharam, pois os enxergam como "folhas em branco" para serem preenchidas com os seus valores e objetivos. No tocante à fast fashion, as seleções e contratações, em sua maioria, eram feitas via empresa terceirizada como Manpower e Gelre. Em raras exceções, a fast fashion fazia uma contratação de algum funcionário de maneira direta, sem a intermediação de uma terceirizada; esses funcionários contratados diretamente já entravam como efetivos ou estáveis.

19 Os nomes de todos os sujeitos que aparecem aqui são fictícios.

20 Ao ser chamado de "Negão" percebo um aspecto muito importante que nos remete à dimensão racializada das interações de Matheus no seu cotidiano e nas relações de trabalho (visto mais a frente). Nessas interações (mesmo sem entendê-lo ainda claramente) Matheus verá que suas marcas corporais ou fenotípicas que remetem à sua negritude (a cor, o cabelo), funcionam como um marcador racial nas relações sociais. Pouco a pouco, dentro e fora do trabalho, Matheus vai perceber as barreiras raciais que se apresentam para ele em suas relações de trabalho. Entretanto, para Matheus, no sentido utilizado por seus amigos, o termo "Negão" é uma forma habitual e cordial de tratamento. Mesmo recebendo esse tipo de interpelação, fortemente racializada, dos seus amigos na escola, nos treinos de Judô e nas relações de trabalho, isso em nenhum momento 
Você acha que eles contratarão um preto? Olhe em volta e veja se tem algum negro trabalhando aqui. Sai fora! ${ }^{21 "}$ Fiquei olhando a loja calmamente, em busca de motivos e fatos para contrapô-lo rapidamente, e não consegui. Mas a vontade de ter o emprego era maior. Confesso que não liguei para o que esse meu amigo disse sobre o fato de ter ou não ter negro na loja. Tinha uma força no momento e uma convicção que me davam a certeza de que conseguiria uma chance, e não a desperdiçaria ${ }^{22}$. Acreditava que era capaz de trabalhar ali; e porque tinha esta determinação, fui em frente. Peguei a ficha para preencher em casa, colocar a minha foto e entregar num dia com mais calma.

o deixava desconfortável. Para ele, mesmo sendo chamado de "Negão" por amigos brancos ou negros, esse tratamento só ressoava positiva ou negativamente dependendo do tom e do contexto em que essa expressão fosse pronunciada.

21 Apesar de Matheus não saber se Nelson tinha algum envolvimento com o movimento negro, pois ele nunca mencionou nada, nem se ele tinha algum familiar envolvido ou militante, foi surpreendente ver como Nelson, um jovem negro, mais velho alguns anos que Matheus, de imediato havia mapeado racialmente o ambiente da loja - com a presença de vendedores ou funcionários predominantemente brancos. Não consigo afirmar que havia um direcionamento para um determinado grupo racial (branco), mas se pensar bem, no contexto do bairro que tem uma constituição populacional de classe média e alta, de maioria branca, e tomando em conta que se tratava de um formulário para preenchimento de candidatos que continha na sua capa dois jovens brancos, fica difícil não cair na suposição de que havia uma certa preferência por jovens brancos. Mesmo achando difícil que a empresa estivesse adotando uma ação estratégica para contratar apenas brancos, a realidade que se mostrava aos olhos de Matheus e dos seus amigos não deixava dúvidas: ali havia apenas pessoas brancas. Pensando no presente, percebemos o quanto se avançou no que concerne a uma maior presença de negros nas lojas desse tipo de comércio varejista. Durante as observações de campo, nos últimos meses, pude notar lojas com uma presença relevante de negros. Isso deixa entrever possíveis marcas das mudanças nas estratégias e políticas de contratação dessas empresas, que hoje estão voltadas para políticas de inclusão racial e em prol da diversidade.

22 Aqui nessa passagem enxergo a presença de um possível mecanismo que possibilita superar as barreiras que se impõem ou "invisibilizá-las" por determinado tempo até achar uma forma de ultrapassá-las. Percebe-se que Matheus, mesmo sendo alertado por Nelson sobre a não existência de negros, opta por não dar importância a tal fator e se apega a uma determinação, ou um desejo, de conseguir a oportunidade de trabalho. É como se ele não quisesse acreditar ou se deixar levar pelos imperativos de possíveis barreiras raciais que seriam capazes de lhe anular e não deixar que ele tivesse a mínima chance de concorrer ao emprego. Dito de outra maneira, Matheus tornou o fenômeno apontado por Nelson "invisível" - como uma medida estratégica para não ter o seu objetivo desviado por suas reflexões ou subjetivações, antes mesmo de vivenciar a oportunidade do processo seletivo. Para ser franco, creio que Matheus, mesmo sabendo que as barreiras estariam colocadas no seu caminho, nutriu um sentimento de que, no momento exato da entrevista ou seleção, poderia demonstrar seu valor e suas potencialidades, ou seja, achar uma brecha que o fizesse seguir o seu percurso, sem que fosse necessário entrar em rota de colisão naquele determinado momento. Dessa forma, invisibilizando ou não as barreiras, em que momento se decide agir assim? Quando se usa esse mecanismo e em que momento? Existe, nisso, alguma motivação que cria um tipo de "escala", um cálculo racional de vantagens relativas, que vai ponderar o que mais importa em determinado momento para o sujeito, como Matheus? Penso que poderiam estar na balança, como dois pratos, por um lado, a sua necessidade do emprego frente à (no outro prato da balança) decepção de ser discriminado na seleção ou mesmo na relação de emprego. De onde vem a segurança para tentar e "crer em si" (apesar das marcas fenotípicas que se crê jogariam contra)? Tal segurança de si seria dada pela educação? Pelo suporte familiar? Como isso aparecerá nos relatos biográficos a serem colhidos doravante? No caso de Matheus, entendo que a sua ação esperançosa e focada se justifica por sua "determinação a arranjar um emprego", pela necessidade subjetiva da autonomia. 
[...] Entre dinâmicas de grupo e conversas ao longo da tarde, chegou o momento de anunciarem os aprovados. Lembro-me de ter visto muitas mulheres levantando, brancas, estatura média, cabelos lisos; novamente, não vi nenhuma negra. Entre os homens, seguindo o mesmo padrão estético, observava brancos e até uns com tom de pele um pouco mais claro que o meu (pardos), mas nenhum com cabelo crespo ou traços que, como um conjunto, demonstrassem um fenótipo negro. $\mathrm{O}$ anúncio dos aprovados seguia um ritual. Cada um dos candidatos selecionados, um por um, ia se levantando e, nesse momento, a supervisora da loja tornava pública a sua avaliação. Assim, num tom altamente subjetivo, descrevia o que cada candidato tinha como destaque positivo, o cargo que iria assumir e o que precisava fazer no dia-a-dia para executar positivamente a sua função; ou seja, quais eram seus de atributos subjetivos e físicos que os tornavam aptos para assumirem o cargo para o qual estavam sendo recrutados. Nessas descrições eram apontados os aspectos ou atributos que as avaliadoras julgaram ser os mais representativos que os futuros funcionários demonstraram durante todas as dinâmicas e também as características que os cargos exigiam de cada um.

Assim, na dinâmica para definição de cargos, a supervisora da empresa, acompanhada de outra senhora que tinha a função de sênior - antiga denominação dos cargos na loja $\mathrm{X}$ - e da representante da empresa de terceirizados (sendo que todas elas eram brancas), após a maioria dos candidatos terem se apresentado, falando sobre suas questões pessoais e aspirações futuras, definiu e explicou que tipo de habilidades ou características os funcionários deveriam ter para exercer o trabalho. Quando chegou a minha vez, mesmo depois de falar das minhas aspirações, ela me disse o seguinte - "Você fique tranquilo, pois, a sua função não necessita que você faça cálculos ou raciocine; o que precisa mesmo é de força. Como já estou vendo que você é forte, você se dará bem”. E, assim, fui selecionado para o setor de estoques, onde uma das minhas principais funções era descarregar e carregar caminhões com mercadorias ${ }^{23}$.

O peso das marcas corporais apareceria aqui e ali na minha experiência. Apesar dessas várias manifestações da discriminação nesse processo seletivo, só

23 Nessa longa passagem, fica evidenciado o quanto os processos seletivos podem assentar-se em avaliação altamente subjetiva e com um direcionamento em termos raciais. No caso da seleção de Matheus, mesmo sem que a supervisora tivesse precisado mencionar uma palavra sobre a questão racial, nem aludido a qualquer das marcas raciais que me identificavam, transparecia, como evidente, que, quando um negro, como "Matheus", assume sua capacidade de ultrapassar essa barreira da discriminação, a firma, através da ação de uma supervisora (consciente ou inconsciente) o coloca no seu "lugar". E o lugar de negro, jovem e forte, é no estoque, carregando peso, já que, em nossa sociedade, negro forte é feito para o trabalho braçal. O comportamento discriminador parecia livre para pautar, ao menos naquele momento e naquele contexto, os processos de seleção dessa empresa. Pela primeira vez, Matheus percebe estar sendo objeto de um comportamento discriminatório na empresa. 
alguns anos à frente, quando já era um efetivo e realizava contratações, testemunhei essa discriminação se manifestar na atitude de um supervisor. Esse é um dos episódios que me vem à memória como relevante. Naquele momento, eu tinha selecionado um trabalhador temporário que era gordo; tão obeso que quase não se encontrava uniforme para ele trabalhar. Rapaz muito simpático, sorridente e comunicativo, decidi colocá-lo no Caixa de Vendas (um setor da loja), e ele se deu muito bem. Estava executando bem as funções e vendendo bem o parcelado com juros; tudo ia a contento, até quando o supervisor o viu e veio a ter comigo, cobrando uma satisfação sobre aquela cena. Perguntava sobre algo que havia de errado no Caixa. Percebendo do que se tratava, agi ironicamente e disse que não estava entendendo e que não via nada de errado. O supervisor se irrita e pergunta quem contratou "aquele cara gordo" dizendo que queria que ele saísse de lá imediatamente. Relutei para dizer quem o contratara, observando para ver até onde ia o preconceito do supervisor; segurei a resposta até onde deu. O supervisor esbravejava, afirmando que ele não tinha o "perfil da empresa" e que, por isso, não deveria estar ali. Nesse momento, disse que fui eu quem o havia selecionado. O supervisor olha assustado e pergunta se eu havia perdido a noção. Em seguida, como uma forma de resolver esse problema, ordena que o mande para a Reserva - o setor de estoque. Com esta solicitação, enfim, fechei o ciclo de dúvidas, se alguma ainda havia, sobre a minha alocação na Reserva quando fui selecionado. Os dois, eu e o temporário obeso, não tínhamos o perfil da empresa, de acordo com aquela recomendação do supervisor.

\section{POR UM MÉTODO DE PESQUISA SOCIOLÓGICO E AUTOETNOGRÁFICO: ALGUMAS CONSIDERAÇÕES FINAIS}

Pelo visto até aqui, há que concluir sublinhando que, apesar do seu enorme valor heurístico para a pesquisa de doutorado que estou desenvolvendo, a autoetnografia não será o único método a ser usado no trabalho de campo ${ }^{24}$. Por mais importantes que sejam suas propostas e abrangência, bem como por mais relevantes que sejam os aspectos críticos e políticos que lhe constituem e potencializam seu relevo para os estudos e o debate sobre a construção de identidades ${ }^{25} \mathrm{e}$ representações, não se pretende restringir o ferramental de campo somente a esse método. Ao ser utilizado na pesquisa sociológica em sintonia com outros métodos, alcançar-se-á uma profundidade analítica maior no que tange às compreensões e interpretações acerca do objeto de estudo.

24 Nesse momento da pesquisa, algumas entrevistas biográficas e observações etnográficas já foram conduzidas no contato preliminar com o campo.

25 Ver Parry (2007). 
Dessa forma, partiremos dos processos mais micro das experiências vivenciadas por Matheus nas relações sociais e em especial no trabalho, para dali recuperar as questões macro que dão corpo às relações raciais e às discriminações nos locais de trabalho, e consequentemente depreender os impactos sobre o curso da ação dos indivíduos e organizações, decorrentes dessas interações (onde desigualdades se evidenciam e são, com frequência, vividas sob o signo da discriminação). A autoetnografia oferecerá a base para que façamos esse percurso autorreflexivo e analítico sobre as experiências e ações dos sujeitos da pesquisa e ao mesmo tempo dos sujeitos pesquisadores - em relação/interação. Essas relações, conquanto expressas/vividas no plano micro, são sempre travestidas e/ou perpassadas por macroprocessos - culturais, políticos, sociais, aí compreendidos os fatores étnicos e raciais, as questões de gênero e orientação sexual, entre outros -, de onde extraem seus significados.

Vimos que esse caminho metodológico coloca desafios, até porque a autoetnografia sofre a recusa, e também se choca, com algumas concepções "tradicionais e canônicas" da pesquisa científica. Esse choque tem no seu cerne um complexo dilema acerca da tão almejada "neutralidade" no desenvolver da pesquisa e, principalmente, na análise dos resultados da investigação. Se não deixa de ser plausível que o pesquisador ou o sujeito da pesquisa deva procurar ser neutro para não interferir nos resultados e processos da investigação sociológica, disso não se deve (apressadamente) concluir que, caso esse sujeito pesquisador reconheça os processos mais subjetivos que o levam para o tema e advogue o valor da sua experiência como um dos principais fatores propulsores da investigação, a sua pesquisa deixe de ter valor científico. Pelo contrário, o reconhecimento dessas questões, em nosso entender, e em sintonia com os autores da autoetnografia, só ampliará a nossa lente de investigação, possibilitando observar fenômenos de maneira mais ampla e, ao mesmo tempo, mais detalhada, evidenciando-lhes novas formas e contornos.

Isso porque, e para concluir, é importante reter o elo entre a dimensão do indivíduo e as questões macrossociais. É a partir das interações desses indivíduos, inclusive com os sujeitos pesquisadores, que poderemos estar mais próximos de captar o sentido das representações sociais e das estratégias individuais, permitindo um grau de análise mais acurado. A autoetnografia vem reforçar o vigor e a reflexividade de um conhecimento que advoga o relevo dos microprocessos (individuais) para o entendimento dos processos macrossociais, como a desigualdade, a discriminação, o racismo institucional - que interessam mais de perto a este trabalho. 


\section{REFERÊNCIAS BIBLIOGRÁFICAS}

Adams, Tony; Ellis, Carolyn; Jones, Stacy;. Autoethnography: Understanding Qualitative Research Series. New York, NY: Oxford University Press, 2015.

Adams, Tony; Bochner, Arthur; Eldis, Carolyn. Autoethnography: an overview. Historical Social Research, v. 36, p. 273-290, 2011.

AndERson, Leon. Analytic Autoethnography. Journal of Contemporary Ethnography, v. 35, p. 373-395, 2006.

Atkinson, Paul. Rescuing Autoethnography. Journal of Contemporary Ethnography, vol. 35, n. 4, p. 400-404, 2006.

Bochner, Arthur; Eldis, Carolyn. "Autoethnography, Personal Narrative, Reflexivity."

In: Denzin, Norman; Lincoln, Yvonna (orgs.). Handbook of qualitative research, Thousand Oaks: Sage, 200o, p.733-768. . Composing ethnography: alternative forms of qualitative writing. Walnut

Creek: AltaMira Press, 1996.

. Analyzing analytic autoethnography: An autopsy. Journal of Contemporary Ethnography, v. 35, n. 4, p. 429-449, 2006.

Bosı, Ecléa. Memória e sociedade: lembrança de velhos. São Paulo: Companhia das Letras, 1994.

Bourdieu, Pierre. Esboço de auto-análise: São Paulo: Companhia das Letras, 2005.

Boylorn, Robin. "A Story \& A Stereotype: An Angry and Strong Auto/Ethnography of Race, Class and Gender." In: BoYLORN, Robin; ORBE, Mark (org.). Critical autoethnography: intersecting cultural identities in everyday life. Walnut Creek: Left Coast Press, 2014, p.129-143.

Chang, Heewon. Autoethnography as method. Walnut Creek, CA: Left Coast Press, 2008. CHoI, Tsan-Ming. Fast fashion systems: theories and applications. London: CRC Press/ Balkema and Taylor \& Francis Group, 2014.

Coffey, Amanda. The ethnographic self: Fieldwork and the representation of identity. London: Sage, 1999.

Delamont, Sara. Arguments against auto-ethnography. Qualitative Researcher, v. 4, p. $2-4,2007$.

Denzin, Norman; Lincoln, Yvonna. "Introduction: The discipline and pratice of qualitative research.” In: Denzin, Norman; Lincoln, Yvonna (orgs.). Handbook of qualitative research, Thousand Oaks: Sage, 2000, p.1-28.

Doloriert, Clair; Sambrook; Sally. Organisational autoethnography. Journal of Organizational Ethnography, v. 1, n. 1, p. 83-95, 2012.

Du Bors, William. As almas da gente negra. Rio de Janeiro: Lacerda Editora, 1999[1903]. 
. The Study of the Negro Problems. The Annals of the American Academy of Political and Social Science, v. 11, p. 1-23, 1898.

The Philadelphia Negro: a social study. New York: Schocken Books, 1899.

ElLIs, Carolyn. The Ethnographic I: A Methodological Novel About Autoethnography. Walnut Creek: AltaMira Press, 2004.

ELLIS, Carolyn; FLAHERTY, Michael. Investigating subjectivity: research on lived experience. Newbury Park, California: Sage Publications, 1992.

Goldschmidt, Walter. Anthropology and the Coming Crisis: An Autoethnographic Appraisal. American Anthropologist, v. 79, n. 2, p. 293-308, 1977.

GrIFFIN, Rachel Alicia. I am an angry black woman: Black feminist autoethnography, voice and resistance. Women's Studies in Communication, v. 35, n. 2, p. 138-157, 2012.

Hayano, David M. Auto-ethnography: Paradigms, Problems and Prospects. Human Organization, v. 38, n. 1, p. 99-104, 1979.

HeIDER, Karl G. What Do People Do? Dani Auto-Ethnography. Journal of Anthropological Research, vol. 31, n. 1, p. 3-17, 1975.

LÉvi-Strauss, Claude. Tristes trópicos. Lisboa: Edições 10, 1955.

Morris, Aldon D. The scholar denied: W. E. B. Du Bois and the birth of modern sociology. Oakland: University of California Press, 2015.

PARrY, Ken W. Constructing identity: An organizational autoethnography. Australian and New Zealand Academy of Management (ANZAM) Annual Conference, p. 1-16, 2007. Reed-Danahay, Deborah. "Introduction.” In: Reed-Danahay, Deborah. Auto/Ethnography: Rewriting the Self and the Social, New York: Berg, 1997.

Romo, Jaime J. Experience and Context in the Making of a Chicano Activist. The High School Journal, v. 87, n. 4, p. 95-111, 2004.

Salzman, Philip Carl. On Reflexivity. American Anthropologist, v. 104, n. 3, p. 805-813, 2002.

SAntos, Silvio Matheus Alves. Otrabalhoflexível no comérciovarejista: multifuncionalidade e precarização. Dissertação (Mestrado). Universidade Federal de São Carlos, São Carlos, 2013, 115 p.

Shantz, Jeffrey. Biographical Sociology: Struggles over an Emergent Sociological Practice. a/b: Auto/Biography Studies, v. 24, n. 1, p. 113-128, 2009.

SNyder, Martha. Leaning into autoethnography: A Review of Heewon Chang's Autoethnography As Method. The Qualitative Report, v. 20, n. 2, p. 93-96, 2015. Disponível em: http://www.nova.edu/ssss/QR/QR20/2/snyder2.pdf. Acesso em: 07 de Junho de 2016.

Stanley, Liz. On Auto/Biography in Sociology. Sociology, v. 27, n. 1, p. 41-52, 1993. WEBER, Max. A “objetividade” do conhecimento nas ciências sociais. São Paulo: Ática, 2006. 